\title{
Cyclin-dependent kinase-5 prevents neuronal apoptosis through ERK-mediated upregulation of Bcl-2
}

\author{
CX Wang ${ }^{1,4}$, JH Song ${ }^{1,2,4}$, DK Song ${ }^{1,2}$, VW Yong ${ }^{3}$, A Shuaib ${ }^{1}$ and \\ C Hao ${ }^{\star 1,2}$ \\ 1 Departments of Medicine and Laboratory Medicine \& Pathology, University of \\ Alberta, Edmonton, Canada \\ 2 Department of Pathology \& Laboratory Medicine, Winship Cancer Institute and \\ Center for Neurodegenerative Disease, Emory University School of Medicine, \\ Atlanta, Georgia, USA \\ ${ }^{3}$ Department of Oncology and Clinical Neurosciences, University of Calgary, \\ Calgary, Canada \\ 4 These two authors contributed equally to this work \\ * Corresponding author: C Hao, Department of Pathology \& Laboratory \\ Medicine, Emory University School of Medicine, 13645-C Clifton Road \\ Atlanta, GA 30322, USA. Tel: + 1-404-778-4776; \\ Fax: + 1-404-778 5550; E-mail: chao@emory.edu
}

Received 15.4.05; revised 04.8.05; accepted 06.9.05; published online 04.11.05 Edited by P Nicotera

\section{Abstract}

Cyclin-dependent kinase-5 (Cdk5) is required for neuronal survival, but its targets in the apoptotic pathways remain unknown. Here, we show that Cdk5 kinase activity prevents neuronal apoptosis through the upregulation of $\mathrm{Bcl}-2$. Treatment of SH-SY5Y cells with retinoid acid (RA) and brain-derived neurotrophic factor (BDNF) generates differentiated neuron-like cells. DNA damage triggers apoptosis in the undifferentiated cells through mitochondrial pathway; however, RA/BDNF treatment results in Bcl-2 upregulation and inhibition of the mitochondrial pathway in the differentiated cells. RA/BDNF treatment activates Cdk5-mediated PI3K/Akt and ERK pathways. Inhibition of Cdk5 inhibits PI3K/ Akt and ERK phosphorylation and $\mathrm{Bcl}-2$ expression, and thus sensitizes the differentiated cells to DNA-damage. Inhibition of ERK, but not PI3K/Akt, abrogates Cdk5-medidated Bcl-2 upregulation and the protection of the differentiated cells. This study suggests that ERK-mediated $\mathrm{Bcl}-2$ upregulation contributes to BDNF-induced Cdk5-mediated neuronal survival.

Cell Death and Differentiation (2006) 13, 1203-1212. doi:10.1038/sj.cdd.4401804; published online 4 November 2005

Keywords: apoptosis; Bcl-2; Cdk5; ERK; neurons; PI3K

Abbreviations: Cdk5, cyclin-dependent kinase-5; RA, retinoid acid; BDNF, brain-derived neurotrophic factor; PI3K, phosphatidylinositol-3 kinase; MAPK, mitogen-activated protein kinase; ERK, extracellular-signal-regulated kinase; NGF, Nerve growth factor; siRNA, small interfering RNA

\section{Introduction}

Cyclin-dependent kinase-5 (Cdk5) was initially identified as a member of the cyclin-dependent kinase family of serine/ threonine kinases based on sequence homology. ${ }^{1}$ In contrast to other Cdk family members, however, Cdk5 is not involved in cell-cycle regulation. Cdk5 shows no enzymatic activity as a monomer, but Cdk5 becomes activated once it interacts and forms a heterodimer with its activator p35 (NCK5a, neuronal Cdk5 activator) ${ }^{2}$ or p39 (NCK5ai, neuronal Cdk5 activator isoform). ${ }^{3}$ Cdk5 is expressed in all tissues, but its kinase activity is predominantly observed in postmitotic neurons of the nervous system ${ }^{4}$ because the Cdk5 activators p35 and p39 are expressed almost exclusively in the nervous system. ${ }^{5}$

Cdk5 kinase activity has been implicated in neuronal death and survival. Amyloid $\beta$-peptide ${ }^{6}$ and ischemic insults ${ }^{7}$ induce the conversion of p35 to its truncated form p25, which causes apoptotic death of neurons. In contrast, the association of p35 and Cdk5 is required for neuronal survival and is involved in many processes in neuronal differentiation and functions most notably neurite outgrowth, ${ }^{8}$ cortical lamination, ${ }^{9}$ neuronal migration, ${ }^{10}$ motility and adhesion. ${ }^{11} \mathrm{Cdk} 5$-mediated signals for neuronal survival appear to occur through the activation of phosphatidylinositol-3 kinase (PI3K)/Akt ${ }^{12}$ and mitogenactivated protein kinase (MAPK)/extracellular-signal-regulated kinase (ERK) pathway. ${ }^{13}$ However, the mechanisms by which Cdk5-mediated pathways modulate apoptotic signals for neuronal survival remain to be investigated.

There are two major signaling pathways that control the initiation of apoptosis: the extrinsic pathway through death receptors-mediated, caspase-8-initiated cleavage of caspase- $3^{14}$ and the intrinsic pathway mediated by mitochondria. ${ }^{15}$ The intrinsic pathway is triggered in response to a wide range of death stimuli such as DNA damage, hypoxia and withdrawal of growth factors, resulting in the mitochondrial release of cytochrome $c .^{16}$ In the cytosol, cytochrome $c$ activates caspase-9, which in turn cleaves caspase-3, leading to apoptosis. ${ }^{17}$ The intrinsic pathway is regulated by $\mathrm{Bcl}-2$ family proteins: Bax and Bak induce mitochondrial release of cytochrome $c$, whereas $\mathrm{Bcl}-2$ and $\mathrm{Bcl}-\mathrm{X}_{\mathrm{L}}$ inhibit its release. ${ }^{15}$ DNA-damaging agents have been reported to induce apoptosis in neurons through the intrinsic mitochondrial pathway. ${ }^{18}$

Neurotrophins such as nerve growth factor (NGF) and brain-derived neurotrophic factor (BDNF) regulate neuronal survival, development and function. ${ }^{19}$ Deprivation of neurotrophins activates mitochondrial apoptotic pathway. ${ }^{20,21}$ BDNF has been reported to induce neuronal differentiation of human SH-SY5Y cells through activation of p35/Cdk5 kinase activity. ${ }^{21}$ Here, we show that BDNF-induced p35/ Cdk5 kinase activity upregulates $\mathrm{Bcl}-2$ through the ERK pathway during neuronal differentiation, and thus protects the differentiated neuron-like cells from DNA damage-induced apoptosis. Inhibition of Cdk5 with small interfering RNA 
(siRNA) inhibits ERK pathway and downregulates Bcl-2 in human neurons, thus rendering them vulnerable to DNA damage. These results suggest that ERK-mediated $\mathrm{Bcl}-2$ upregulation provides one of the molecular pathways by which p35/Cdk5 mediates neuronal survival.

\section{Results}

\section{The differentiated neuron-like cells become resistant to DNA-damaging agents}

Sequential treatment of the human SH-SY5Y neuroblastoma cell line with retinoid acid (RA) and BDNF generates nearly pure populations of human neuron-like cells, thus providing a model for the study of neuronal differentiation and survival. ${ }^{21}$ Treatment of SH-SY5Y cells with $10 \mu \mathrm{M}$ RA in the culture medium containing $10 \%$ fetal bovine serum resulted in neurite outgrowth that appeared on day 3 and extended on days 4 and 5 (Figure 1a). The cells were then cultured in serum-free culture medium with $100 \mathrm{ng} / \mathrm{ml}$ BDNF for an additional 5 days.
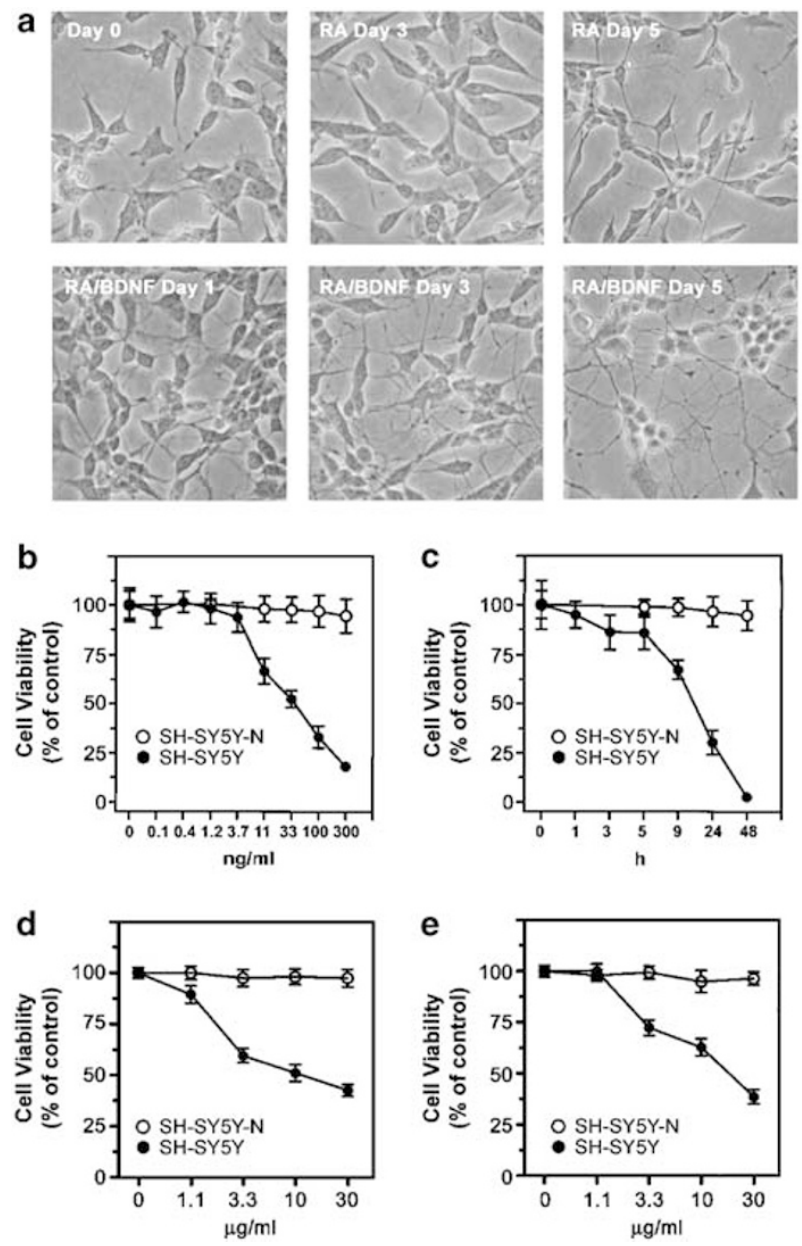

Figure 1 The differentiated SH-SY5Y-N cells are resistant to camptothecininduced cell death. (a) SH-SY5Y cells were differentiated by sequential treatment with RA and BDNF. The undifferentiated SH-SY5Y (O) and the differentiated $\mathrm{SH}-\mathrm{SY} 5 \mathrm{Y}-\mathrm{N}$ cells $(\mathrm{O})$ were treated for $16 \mathrm{~h}$ with various doses of camptothecin (b), etoposide (d) and cisplatin (e) or $30 \mathrm{ng} / \mathrm{ml}$ camptothecin over a time course (c). Cell viability was analyzed by the trypan blue exclusion assay (mean \pm S.E.M.; $n=6$ )
This sequential treatment yielded a nearly pure population of differentiated neuron-like cells (SH-SY5Y-N) characterized by abundant neurite outgrowth (Figure 1a) and expression of neuronal markers such as neurofilaments and neuron-specific enolase. ${ }^{21} \mathrm{SH}-\mathrm{SY} 5 \mathrm{Y}-\mathrm{N}$ cells remained differentiated in the BDNF-containing medium for at the least 3 weeks. In contrast, however, withdrawal of BDNF resulted in a rapid cell death of the differentiated SH-SY5Y-N cells. Approximately, 15 and $45 \%$ of cell death were observed in the differentiated cells 24 and $48 \mathrm{~h}$, respectively, after the cells were left in BDNF-free medium, keeping in line with the previous study. ${ }^{21}$ These results indicate that the differentiated SH-SY5Y-N cells depend on BDNF for survival.

The differentiated cells were then examined for their vulnerability to DNA-damaging agents, as compared to the undifferentiated cells. Both the differentiated and undifferentiated cells were treated with various doses of camptothecin for $16 \mathrm{~h}$ and cell viability analysis showed that camptothecin killed the undifferentiated $\mathrm{SH}-\mathrm{SY} 5 \mathrm{Y}$ cells in a dose-dependent manner $(0.1-300 \mathrm{ng} / \mathrm{ml})$, with an EC50 of $33 \mathrm{ng} / \mathrm{ml}$ (Figure 1b). In contrast, the differentiated SH-SY5Y-N cells were resistant to camptothecin (Figure 1b). SH-SY5Y and $\mathrm{SH}-$ SY5Y-N cells were then treated with $30 \mathrm{ng} / \mathrm{ml}$ camptothecin for various periods of time. The results showed a timedependent cell death of SH-SY5Y but not SH-SY5Y-N cells (Figure 1c). Finally, the cells were treated with other DNAdamaging agents, etoposide (Figure 1d) and cisplatin (Figure 1e), and the results further confirmed that the differentiated cells are resistant to the DNA-damaging insults.

\section{Mitochondrial apoptotic pathway is inhibited in the differentiated neuron-like cells}

There are several lines of evidence that mitochondria play a crucial role for neuronal survival. Camptothecin has been reported to induce apoptosis in rat neurons through activation of mitochondrial pathway. ${ }^{18}$ The findings that the differentiated SH-SY5Y-N cells are resistant to camptothecin suggest that RA/BDNF treatment may result in the inhibition of the mitochondrial apoptotic pathways. We therefore conducted systematic experiments to illustrate signal events through which RA/BDNF may modulate the mitochondrial pathway.

It has been shown that p53 is involved in DNA damageinduced apoptosis through the mitochondrial pathway. ${ }^{22}$ Western blot analysis revealed an increase in the p53 expression in both $\mathrm{SH}-\mathrm{SY} 5 \mathrm{Y}$ and $\mathrm{SH}-\mathrm{SY} 5 \mathrm{Y}-\mathrm{N}$ cells in response to camptothecin treatment, suggesting that the p53-mediated pathway may not play a direct role in the protection of the differentiated cells (Figure 2). Caspase- 8 has been reported to cleave Bid, which then links death receptormediated extrinsic pathway to intrinsic mitochondrial pathway. ${ }^{23}$ Western blots detected no caspase-8 protein in either the differentiated and undifferentiated cells (Figure 2), which is consistent with a report that human neuroblastoma cells lack caspase-8 expression. ${ }^{24}$ Bid cleavage, suggested by the reduced levels of its protein expression (Figure 2), was not observed until other caspases were activated in SH-SY5Y cells. The results indicate that the caspase-8-mediated Bid pathway is inactive in the undifferentiated SH-SY5Y cells. 


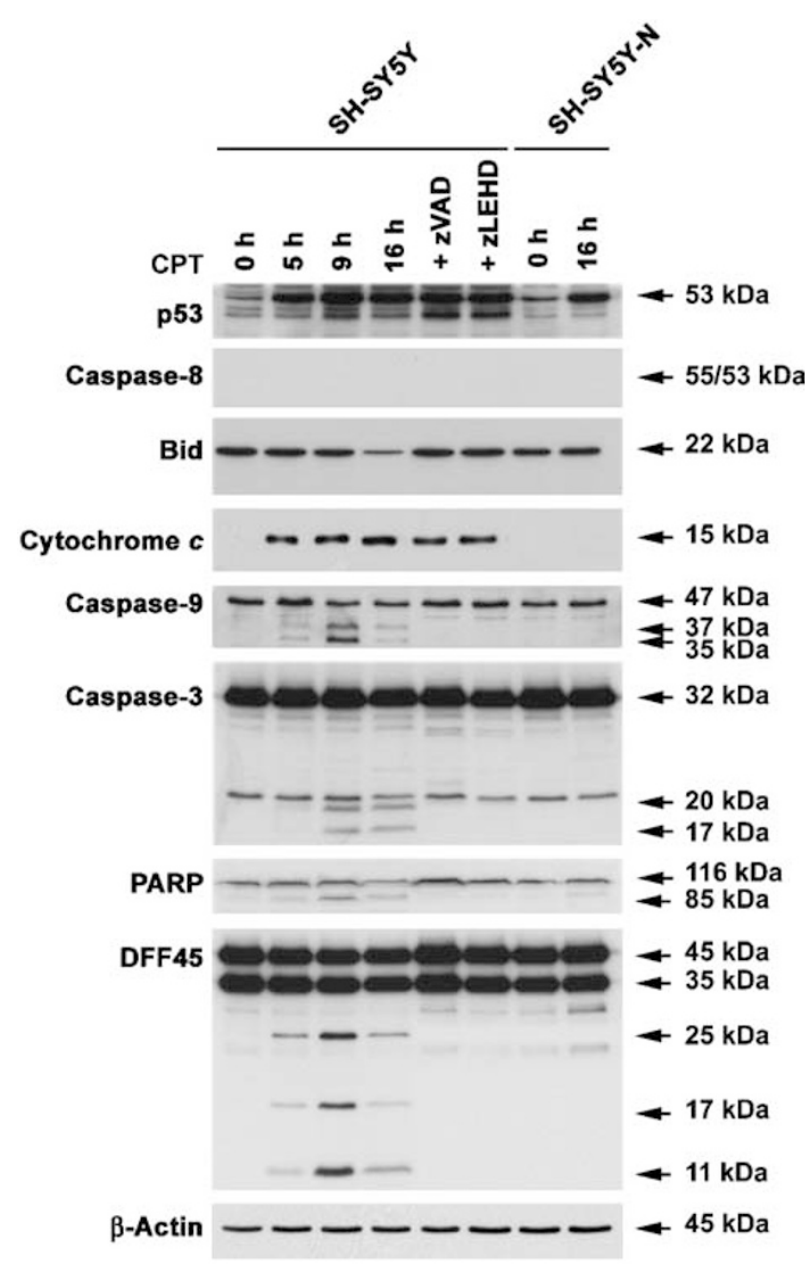

Figure 2 Mitochondrial pathway is inhibited in SH-SY5Y-N cells. SH-SY5Y and SH-SY5Y-N cells were treated with $30 \mathrm{ng} / \mathrm{ml}$ camptothecin for the times indicated. SH-SY5Y cells were also treated with $30 \mathrm{ng} / \mathrm{ml}$ camptothecin (CPT) for $16 \mathrm{~h}$ in the presence of $20 \mu \mathrm{M}$ pan-caspase inhibitor z-VAD-fmk (zVAD) or caspase-9 specific inhibitor z-LEHD-fmk (ZLEHD). The cells were then subjected to Western blot analysis for expression of p53, Bid, and caspase-8, and for the cleavage of caspase-9, caspse-3, PARP and DFF45. Some of the cells were also subjected to subcellular fractionation. The cytosolic fractions that were free of mitochondria were examined by Western blots for the presence of cytochrome $c$ (panel 4). $\beta$-actin was used as protein load control

We then examined mitochondrial release of cytochrome $c$, a crucial event in the activation of mitochondrial pathway. The cells were treated with $30 \mathrm{ng} / \mathrm{ml}$ camptothecin and then subjected to subcellular fractionation. Western blots detected cytochrome $c$ in mitochondria-free cytosolic fractions obtained from SH-SY5Y cells, but not SH-SY5Y-N cells (Figure 2). Western blots also detected cleavage products of caspase-9, caspase-3, poly (ADP-ribose) polymerase-1 (PARP-1) and DNA fragmentation factor 45 (DFF45), a substrate of caspase- $3^{25}$ in SH-SY5Y, but not SH-SY5Y-N cells (Figure 2). Treatment of the undifferentiated cells with caspase- 9 inhibitor carbobenzyloxy-leu-glu( $O$-methyl)-his-asp-( $O$-methy)fluoromethyl ketone (z-LEHD-fmk) or pan-caspases inhibitor carbobenzyloxy-Val-Ala-Asp(Ome)-fluoromethyl ketone (zVAD-fmk) eliminated camptothecin-induced cleavage of caspase-9, caspase-3, PARP-1 and DFF45, but not the upstream mitochondrial release of cytochrome $c$ (Figure 2).

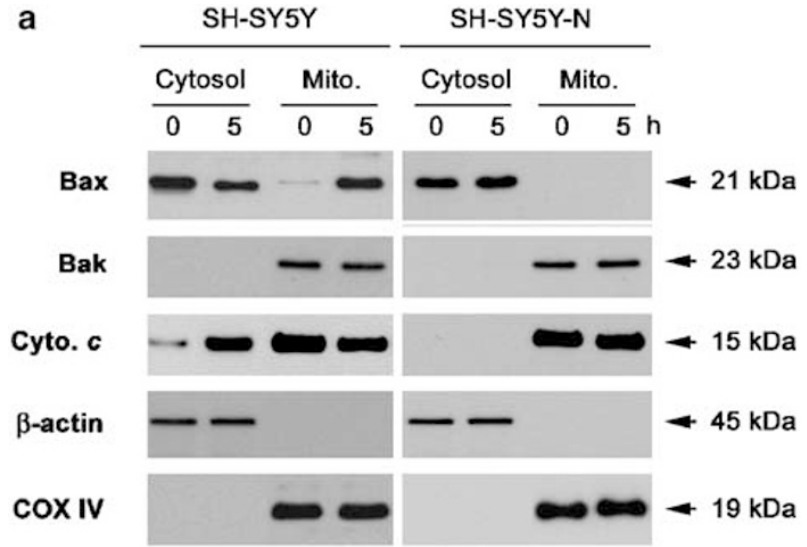

b
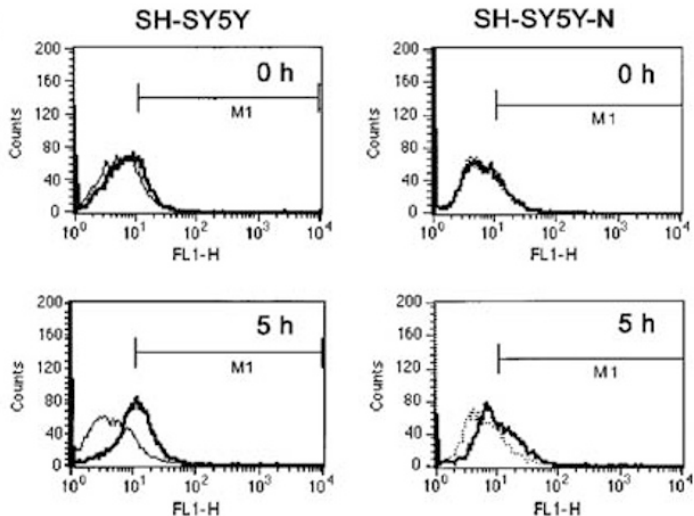

Figure 3 Bax translocation and Bak conformational changes are inhibited in SH-SY5Y-N cells. (a) Subcellular fractionation analysis of Bax and Bak. SHSY5Y (left) and SH-SY5Y-N cells (right) were treated with $30 \mathrm{ng} / \mathrm{ml}$ camptothecin for the times indicated and subjected to subcellular fractionation. Cytosolic and mitochondrial (mito) fractions were subjected to Western blots using antibodies to Bax, Bak and cytochrome $c$ (Cyto. $c$ ). $\beta$-actin and COX IV were used as loading controls for cytosolic and mitochondrial fractions, respectively. (b) Flow cytometry analysis of Bak conformational change. SH-SY5Y (left) and SH-SY5Y-N cells (right) were treated as described above and analyzed by flow cytometry using an antibody against the $\mathrm{NH}_{2}$-terminus of Bak (dark line). Mouse IgG1 antibody was used as a negative control (grey line)

The results indicate that mitochondrial release of cytochrome $c$ is inhibited in the differentiated SH-SY5Y-N cells.

\section{Bcl-2 protects the differentiated neuron-like cells from camptothecin-induced apoptosis}

To explore the molecular mechanisms involved in the mitochondrial inhibition, we examined the roles of Bcl-2 family proteins in camptothecin-induced apoptosis. Bax translocates from the cytosol to the mitochondrial membrane to trigger mitochondrial release of apoptotic factors. ${ }^{26}$ Indeed, Western blot analysis of subcellular fractions revealed a decrease of Bax in the cytosol, but an increase of Bax in the mitochondrion in camptothecin-treated SH-SY5Y cells (Figure 3a). Bak resides in the mitochondrial membrane and Western blots detected Bak in mitochondrial but not cytosolic fractions in both cell types (Figure 3a). DNA damage-induced activation of the mitochondrial pathway occurs through induction of a conformational change in Bak, resulting in the exposure of the $\mathrm{NH}_{2}$-terminus that is normally fold within the Bak protein. ${ }^{27}$ 
Indeed, flow cytometry analysis with the antibody against the Bak $\mathrm{NH}_{2}$-terminus revealed the conformational change of Bak in camptothecin-treated SH-SY5Y cells (Figure 3b). The Bax translocation and Bak conformational change were associated with mitochondrial release of cytochrome $c$ in SH-SY5Y cells after exposure to camptothecin (Figure 3a).

In contrast, subcellular fractionation analysis revealed neither Bax translocation nor mitochondrial release of cytochrome $c$ in SH-SY5Y-N cells treated with camptothecin (Figure 3a); the results suggest that RA/BDNF treatment may result in the inhibition of Bax and Bak expression and/or apoptotic functions. To test this, we first examined expression of Bcl-2 family proteins and showed a gradual decrease in Bak and increase in $\mathrm{Bcl}-2$ expression during the $\mathrm{SH}-\mathrm{SY} 5 \mathrm{Y}$ differentiation (Figure $4 \mathrm{a}$ and $\mathrm{b}$ ). Bcl-2 is well known for its role in inhibition of Bax and Bak apoptotic functions: one study has demonstrated that $\mathrm{Bcl}-2$ inhibit $\mathrm{Bax}$ conformational change through interaction with Bak. ${ }^{28}$ While another study has shown that $\mathrm{Bcl}-2$ prevents $\mathrm{Bax}$ translocation from cytosol to mitochondrial membrane. ${ }^{29}$ We therefore examined the roles of $\mathrm{Bcl}-2$ in the protection of the differentiated neuronal cells from camptothecin-induced apoptosis.

We first inhibited Bcl-2 expression in SH-SY5Y-N cells with small interfering RNA (siRNA). Two synthetic siRNA duplexes (Bcl-2-siRNA1, Bcl-2-siRNA2) targeting $\mathrm{Bcl}$-2 gene were generated; however, only Bcl-2-siRNA1 inhibited $\mathrm{Bcl}-2$ expression in SH-SY5Y-N (Figure 4c). SH-SY5Y-N cells were transfected either with Bcl-2-siRNA1 or Bcl-2-siRNA2 as negative control. The results show that Bcl-2-siRNA1 transfection sensitized SH-SY5Y-N cells to camptothecin-induced apoptosis, as observed by the cleavage of caspase-3 and DFF45 (Figure 4c), cell death (Figure 4d) and cellular apoptosis (Figure 4e).

We then transfected Bcl-2 cDNA in SH-SY5Y cells to determine if $\mathrm{Bcl}-2$ overexpression protects the undifferentiated cells. Once SH-SY5Y cells were transfected with Bcl-2 (Figure 5a), they became resistant to camptothecin-induced apoptosis, as Western blots detected no caspase-3 cleavage

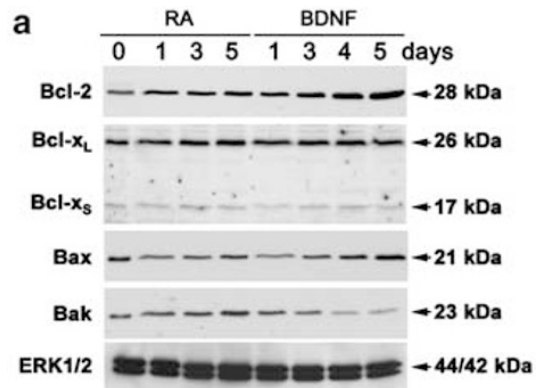

C
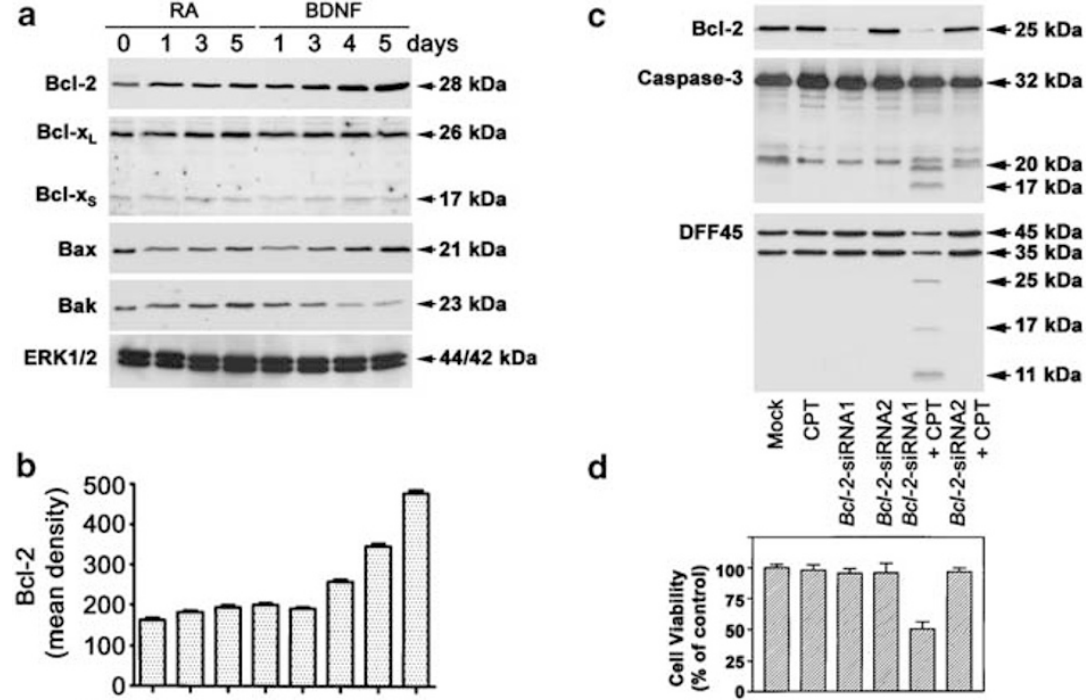

d
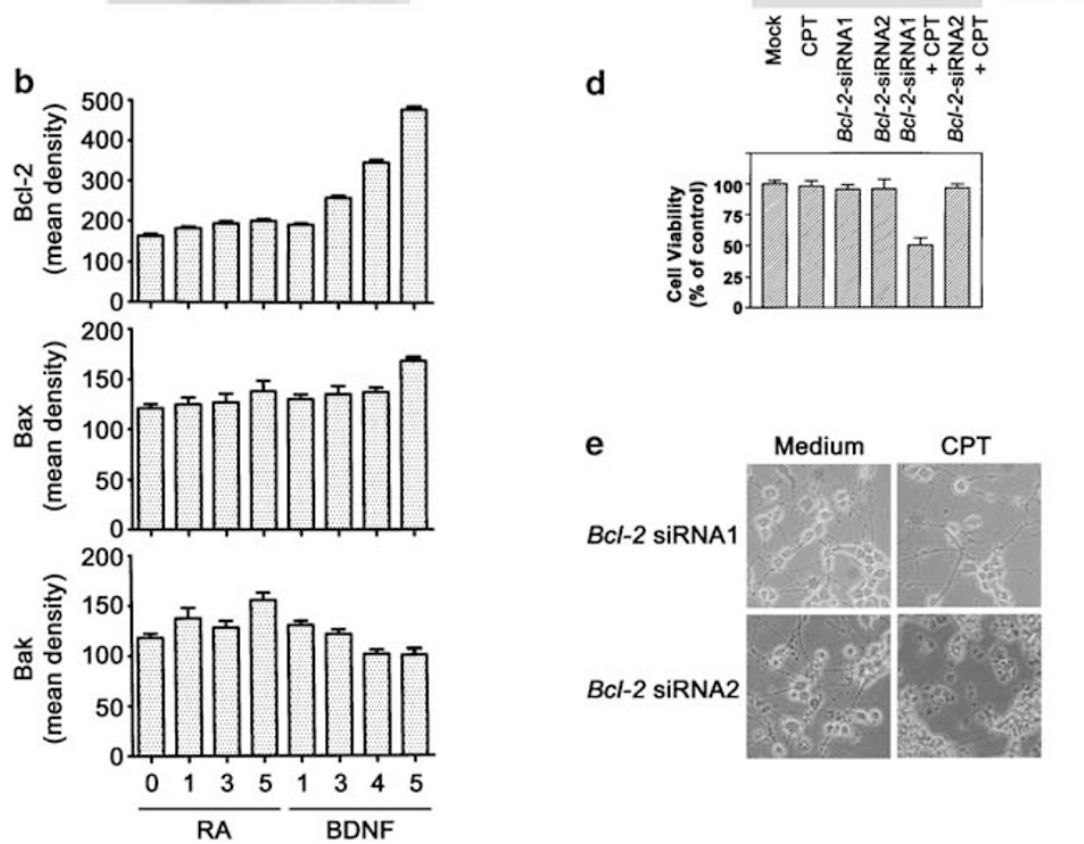

Figure 4 Inhibition of Bcl-2 in SH-SY5Y-N cells sensitizes the cells to camptothecin (CPT)-induced apoptosis. (a) Western blot analysis of the expression of Bcl-2 family proteins during SH-SY5Y differentiation. ERK1/2 was used as protein loading control. (b) The bar graphs show the densitometric analysis of Bcl-2, Bax and Bak expression levels during the SH-SY5Y neuronal differentiation. (c) Western blot detection of Bcl-2 expression and cleavage of caspase-3 and DFF45 in SH-SY5Y-N cells transfected with Bcl-2 siRNA for $24 \mathrm{~h}$ and then treated with $30 \mathrm{ng} / \mathrm{ml}$ camptothecin (CPT) for $5 \mathrm{~h}$. (d) Cell viability analysis of SH-SY5Y-N cells following the treatments described above by trypan blue exclusion analysis. Bars represent mean \pm S.E.M. $(n=6)$. (e) Phase contrast microscopy of cellular apoptosis in SH-SY5Y-N cells transfected with Bcl-2 siRNA for $24 \mathrm{~h}$ and treated with camptothecin for $1 \overline{\mathrm{h}}$ 


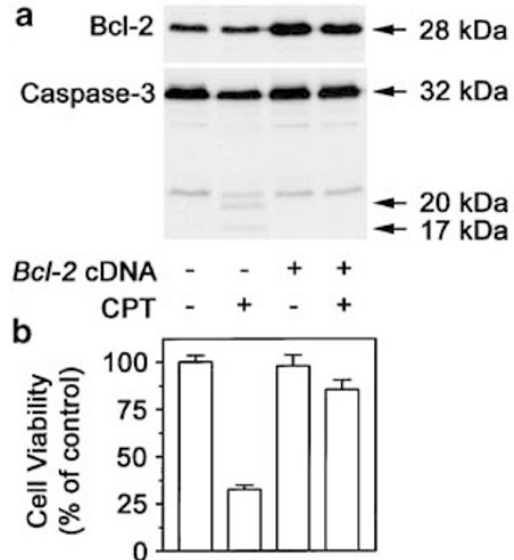

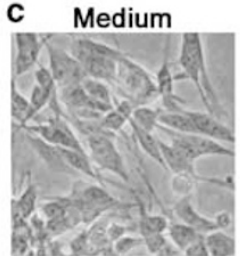

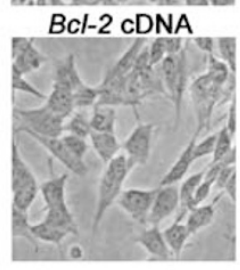

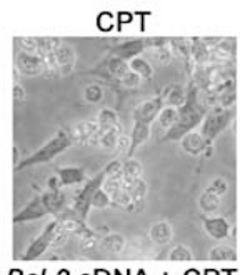

$\mathrm{Bcl}-2 \mathrm{cDNA}+\mathrm{CPT}$

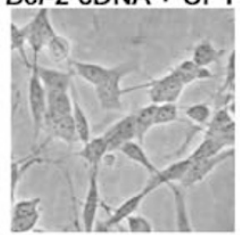

Figure 5 Bcl-2 overexpression protects SH-SY5Y cells from camptothecin (CPT)-induced apoptosis. (a) Western blot analysis of Bcl-2 expression and caspase-3 cleavage in SH-SY5Y cells after the cells were transfected with Bcl-2 expressing vector pUSEamp for $24 \mathrm{~h}$ and then treated with $30 \mathrm{ng} / \mathrm{ml}$ camptothecin (CPT) for $5 \mathrm{~h}$. (b) Cell viability analysis of SH-SY5Y cells transfected with Bcl-2 expressing vector pUSEamp and treated with $30 \mathrm{ng} / \mathrm{ml}$ camptothecin for $16 \mathrm{~h}$ (mean \pm S.E.M.; $n=6$ ). (c) Phase contrast microscopy of cellular apoptosis in SH-SY5Y cells transfected with Bcl-2 pUSEamp for $24 \mathrm{~h}$ and treated with camptothecin for $16 \mathrm{~h}$

(Figure 5a), cell viability analysis revealed no significant cell death (Figure $5 \mathrm{~b}$ ) and phase contrast microscopy showed no cellular apoptosis (Figure 5c). Taken together, these studies with siRNA downregulation of Bcl-2 and Bcl-2 cDNA overexpression suggest that $\mathrm{Bcl}-2$ may play a role in the survival of the differentiated and undifferentiated cells. This prompted us to examine BDNF-induced signal events that lead to Bcl-2 upregulation and neuronal survival during the $\mathrm{SH}-\mathrm{SY} 5 \mathrm{Y}$ cell differentiation.

\section{RA/BDNF activates Cdk5-mediated PI3K/Akt and ERK pathways}

NGF has been reported to upregulate the Cdk5 activator p35 and induce Cdk5 kinase activity in the differentiated PC12 cells. ${ }^{13}$ We therefore examined if BDNF induces p35 and Cdk5 protein expression and Cdk5 kinase activity during the SH-SY5Y differentiation. Western blot analysis showed an increased expression of p35, but not Cdk5 during the neuronal differentiation (Figure 6a). Cdk5 protein was then immunoprecipitated and Cdk5 kinase activity was examined using histon- $\mathrm{H} 1$ as a substrate. The activity of Cdk5 kinase was slightly increased by RA treatment, while the RA/BDNF treatment resulted in much higher Cdk5 kinase activity in SH-SY5Y-N cells (Figure $6 \mathrm{~b}$ and $\mathrm{c}$ ). The results indicate that RA/BDNF treatment upregulates p35 and thus activates Cdk5 kinase during the SH-SY5Y differentiation.

Study of PC12 cells has suggested that p35/Cdk5mediated neuronal survival involves the ERK pathway ${ }^{13}$ and PI3K/Akt pathway. ${ }^{12}$ ERK activation requires phosphorylation by an upstream activator MAPK/ERK kinase (MEK). ${ }^{30}$ Indeed, Western blots detected a significant increase in expression of phosphorylated ERK $1 / 2$ proteins in both RA and RA/BDNF-treated cells (Figure 6a). We then examined the PI3K-mediated phosphorylation of Akt protein. ${ }^{31}$ The phosphorylated Akt protein was detected on Western blots in SH-SY5Y cells after RA treatment while the sequential treatment with RA/BDNF resulted in a higher and sustained
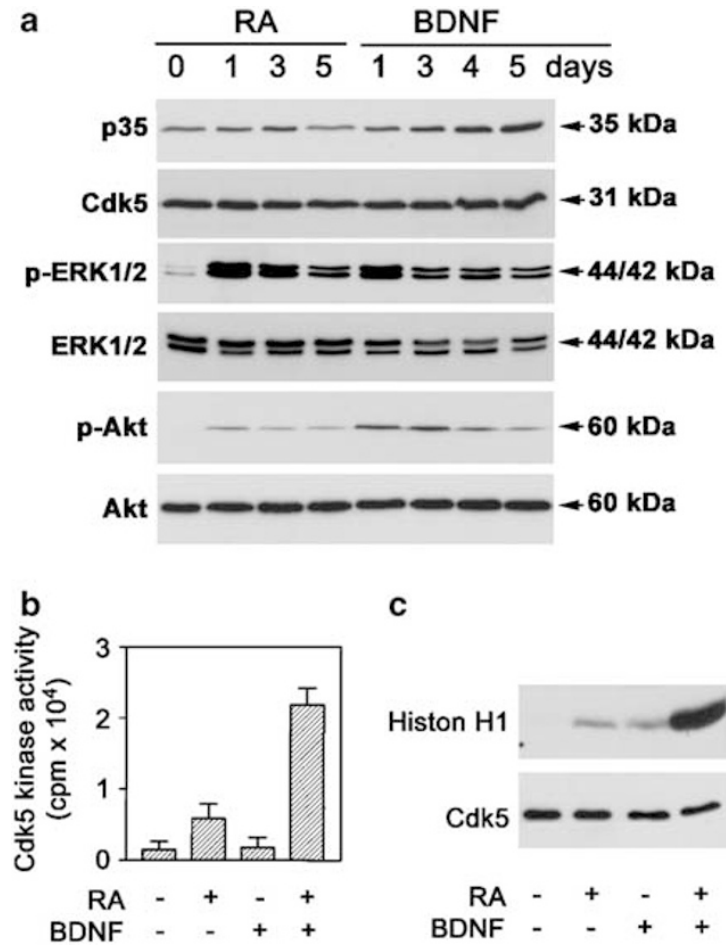

C

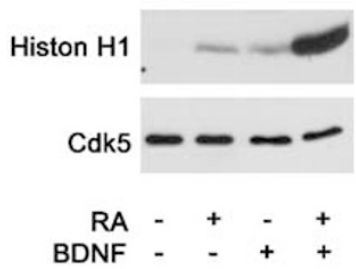

Figure 6 RA/BDNF treatment activates p35/Cdk5 kinase activity. (a) Akt and ERK phosphorylation. SH-SY5Y cells were treated first with RA for 5 days and then with BDNF for additional 5 days and examined by Western blot for expression of p35, Cdk5, phosphorylated ERK1/2 (p-ERK1/2), ERK1/2, phosphorylated Akt (p-Akt), and Akt. (b, c) Cdk5 immunoprecipitation/kinase assays. SH-SY5Y cells were treated with RA for 5 days or sequential RA/BDNF treatments for 10 days and then immunoprecipitated with anti-Cdk5 antibody. Cdk5 kinase activity was measured by radioactivity (b) and Western blot analysis of histon $\mathrm{H} 1$ (c)

expression of phosphorylated Akt (Figure 6a). These results indicate that RA/BDNF activates the ERK and PI3K/Akt pathways during the $\mathrm{SH}-\mathrm{SY} 5 \mathrm{Y}$ cell differentiation. 


\section{Cdk5-mediates Bcl-2 upregulation through ERK pathway}

To define the roles of the PI3K and ERK pathways in Cdk5mediated neuronal survival, we inhibited Cdk5 kinase activity first with the Cdk5 inhibitor roscovitine ${ }^{13}$ and then specifically silenced Cdk5 gene expression with synthetic Cdk5 siRNA. Roscovitine treatment of SH-SY5Y-N cells inhibited Akt and ERK phosphorylation and Bcl-2 expression (Figure 7a), and sensitized the cells to camptothecin-induced apoptosis, as indicated by caspase cleavage (Figure $7 \mathrm{~b}$ ), cell death (Figure 7c) and cellular apoptosis (Figure 7d). Transfection of Cdk5 siRNA in SH-SY5Y-N cells inhibited Cdk5 kinase
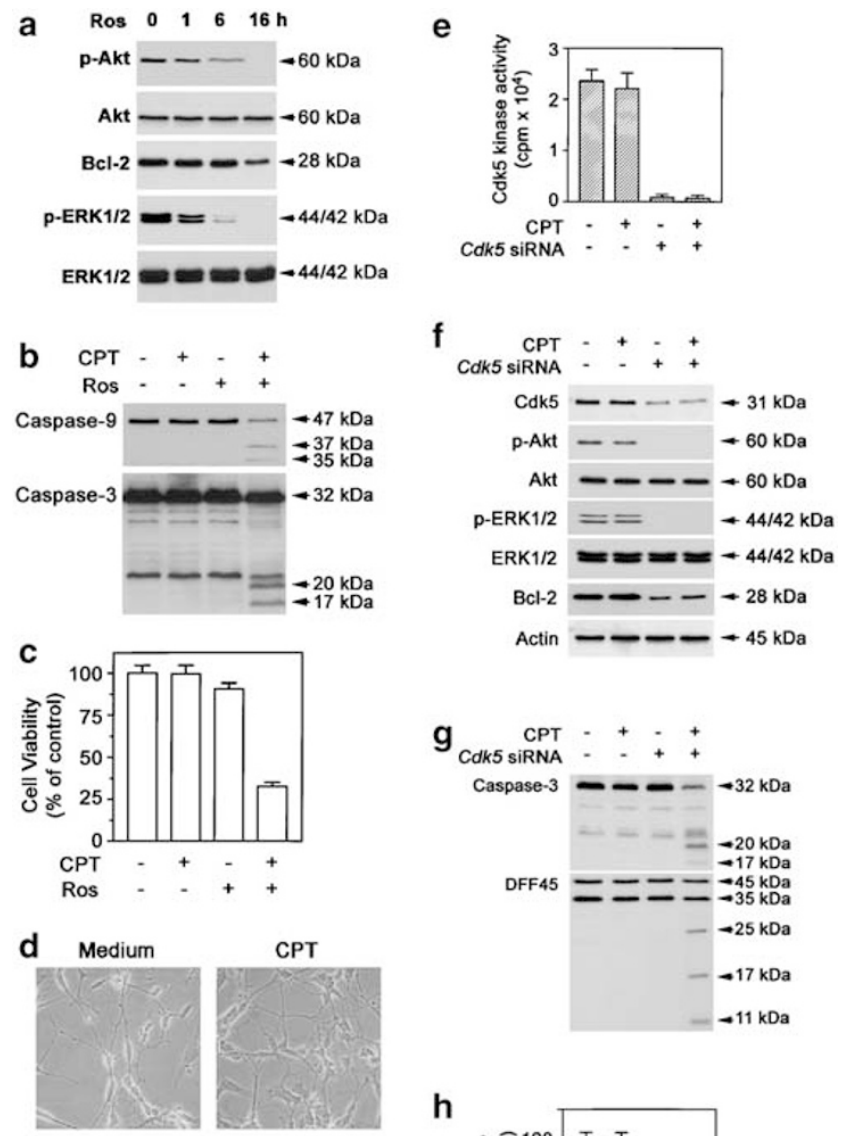

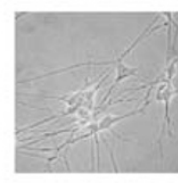

Ros

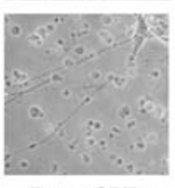

Ros + CPT

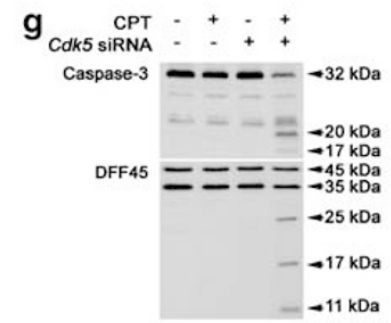

h

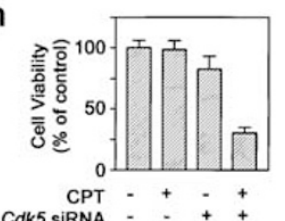

Cdk5 SIRNA - . + +
Figure 7 Inhibition of Cdk5 inhibits Akt and ERK phosphorylation and Bcl-2 expression. (a-d) Treatment with Cdk5 inhibitor roscovitine. SH-SY5Y-N cells were treated with $10 \mu \mathrm{M}$ roscovitine (Ros) and subjected to Western blots for detection of Akt and ERK phosphorylation and Bcl-2 expression (a). SH-SY5Y-N cells were treated with $10 \mu \mathrm{M}$ roscovitine for $16 \mathrm{~h}$ followed by camptothecin treatment for $5 \mathrm{~h}$ to detect cleavage of caspase- 9 and caspase-3 by Western blots (b) or for16 $\mathrm{h}$ to examine cell viability (mean \pm S.E.M.; $n=6$ ) (c) and to examine cellular apoptosis under microscopy (d). (e-h) Cdk5 siRNA transfection. SH-SY5Y-N cells were transfected with Cdk5 siRNA for $24 \mathrm{~h}$ and examined for Cdk5 kinase activity using histon $\mathrm{H} 1$ as a substrate (e). Ckd5 siRNA-transfected cells were treated with camptothecin and examined for protein expression and phosphorylation (f), cleavage of caspases $(\mathbf{g})$ and cell viability (mean \pm S.E.M.; $n=6)(\mathrm{h})$ activity (Figure 7e), Cdk5 and Bcl-2 protein expression and Akt and ERK phosphorylation (Figure 7f). Camptothecin treatment triggered apoptosis in the Cdk5 siRNA-transfected $\mathrm{SH}-\mathrm{Y} 5 \mathrm{Y}-\mathrm{N}$ cells, as demonstrated by caspase-3 and DFF45 cleavage (Figure $7 \mathrm{~g}$ ) and cell death (Figure $7 \mathrm{~h}$ ). The results suggest that the $\mathrm{p} 35 / \mathrm{Cdk5}$-mediated $\mathrm{Bcl}-2$ upregulation may occur through the PI3K and/or ERK pathway.

To differentiate the role of the PI3K and ERK pathway in Cdk5-mediated Bcl-2 upregulation and neuronal survival, we first treated the differentiated cells with the PI3K pharmacological inhibitor LY294002. LY294002 has been shown to have no inhibitory effect on NGF-induced p35/Cdk5 activity. ${ }^{13}$ Treatment of SH-SY5Y-N cells with $50 \mu \mathrm{M}$ LY294002 almost completely inhibited Akt phosphorylation but had no effect on $\mathrm{Bcl}-2$ expression (Figure 8a). Combination treatment of $\mathrm{SH}$ SY5Y-N cells with LY294002 and camptothecin failed to trigger apoptosis in the cells, as demonstrated by Western blot analysis of caspase cleavage (Figure $8 \mathrm{~b}$ ) and cell viability analysis (Figure 8c). These results suggest that Ckd5mediated $\mathrm{Bcl}-2$ upregulation occurs through PI3K/Aktindependent pathways. a
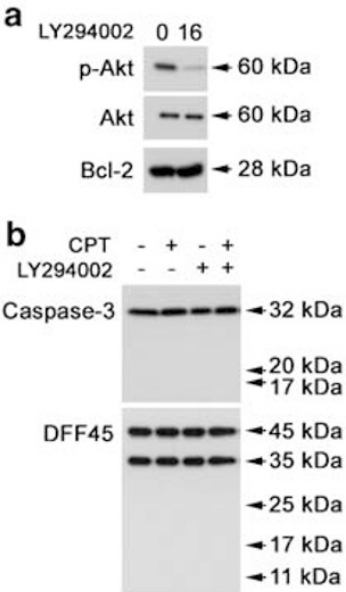

C

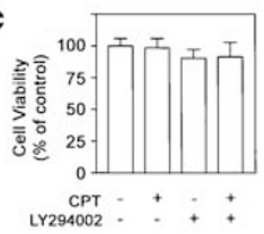

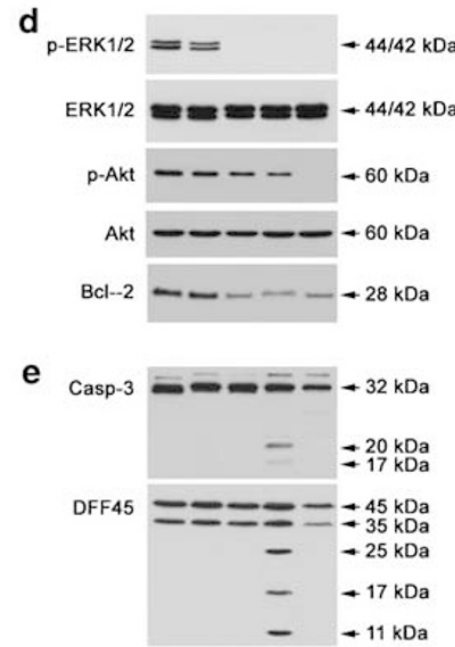

f

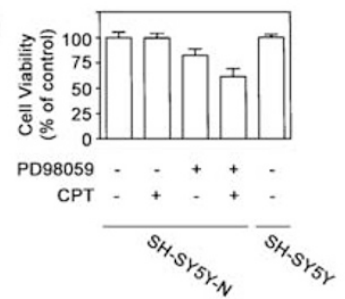

Figure 8 Inhibition of ERK1/2 but not PI3K downregulates Bcl-2 expression. (a-c) Inhibition of PI3K. SH-SY5Y-N cells were treated with $20 \mu \mathrm{M}$ PI3K inhibitor LY294002 for 16 and examined for p-Akt, Akt and Bcl-2 expression on Western blots (a). LY294002 treated cells were then treated with $30 \mathrm{ng} / \mathrm{ml}$ camptothecin (CPT) for $5 \mathrm{~h}$ and subjected to Western blot analysis of caspase-3 and DFF45 cleavage (b) or for $16 \mathrm{~h}$ for cell viability analysis (mean \pm S.E.M.; $n=6)(\mathbf{c})$. (d-f) Inhibition of ERK $1 / 2$. SH-SY5Y-N cells were treated with $50 \mu \mathrm{M}$ the MEK inhibitor PD98059 for $16 \mathrm{~h}$ and then with $30 \mathrm{ng} / \mathrm{ml}$ camptothecin for $16 \mathrm{~h}$ to examine protein expression and phosphorylation by Western blots (d), for $5 \mathrm{~h}$ to detect cleavage of caspase-3 and DFF45 (e) and for $16 \mathrm{~h}$ to examine cell viability (mean \pm S.E.M.; $n=6)(\mathrm{f})$ 
We then treated SH-SY5Y-N cells with PD98059, a specific inhibitor of the $\mathrm{MEK} 1^{32}$ to determine if Cdk5-mediated Bcl-2 upregulation occurs through the ERK pathway. Treatment of SH-SY5Y-N cells with $50 \mu \mathrm{M}$ PD98059 for $16 \mathrm{~h}$ inhibited ERK1/2 phosphorylation as well as Bcl-2 protein expression (Figure 8d), causing a synergistic effect on camptothecininduced apoptosis, as evident by caspase-3 and DFF45 cleavage (Figure 8e) and significant cell death (Figure 8f). Collectively, the results indicate that RA/BDNF-induced Cdk5mediated upregulation of $\mathrm{Bcl}-2$ expression occurs through the activation of the ERK1/2 pathway. This ERK1/2-mediated Bcl2 upregulation may provide one of the molecular pathways for Cdk5-mediated neuronal survival.

\section{Cdk5 contributes to BDNF neuroprotection of primary human neurons}

These studies of SH-SY5Y cell line suggest that the Cdk5mediated Bcl-2 expression occurs through ERK pathway during neuronal differentiation. To determine if the Cdk-5- mediated Bcl-2 pathway also plays role in the survival of primary human neurons, we generated enriched (over $90 \%$ purity) cultures of human neurons (Figure 9a), based on the protocols as we previously reported. ${ }^{33}$ The human neurons were first treated with various doses of camptothecin and the cell viability assay showed that camptothecin killed primary human neurons in a dose dependent manner with toxicity manifesting at camptothecin concentrations of more than $100 \mathrm{ng} / \mathrm{ml}$ (Figure 9b). Next, we examined the human neurons to determine if Cdk5-mediated ERK and Bcl-2 signal pathway contributes to BDNF-induced neuroprotection of the primary human neurons.

BDNF has been reported to activate ERK1/2 in cortical rat neurons and ERK $1 / 2$ activation reaches its peak at $7 \mathrm{~h}$ and maintained for $12 \mathrm{~h}$ under the BDNF treatment. ${ }^{34}$ To examine the role of BDNF-mediated Cdk5 pathway in the survival of human neurons, we transfected the human neurons with Cdk5 siRNA for $24 \mathrm{~h}$ to inhibit Cdk5. The Cdk5 siRNAtransfected neurons were then treated with $300 \mathrm{ng} / \mathrm{ml}$ BDNF for $6 \mathrm{~h}$ and subjected to Western blots analysis. Western blots
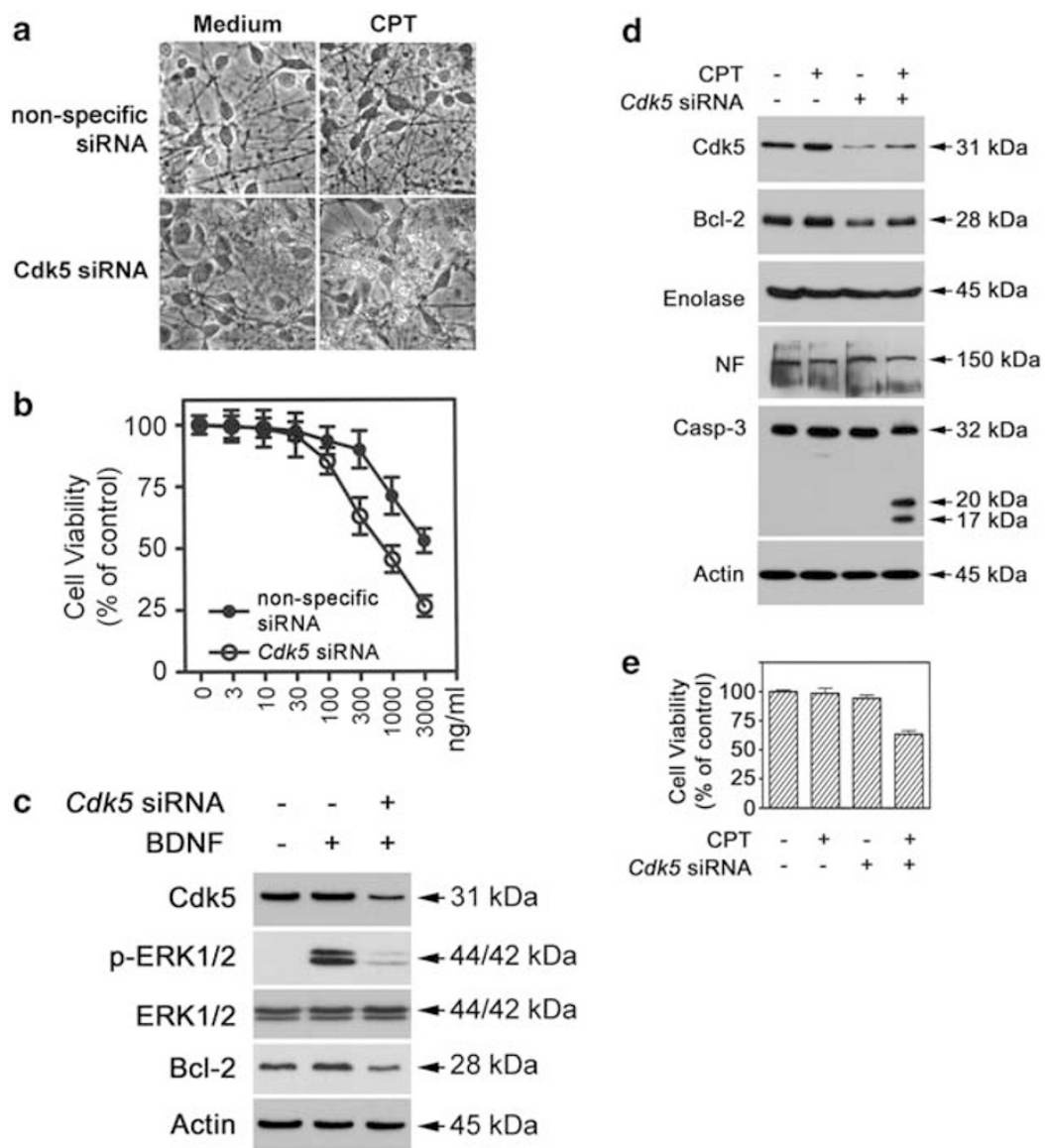

e

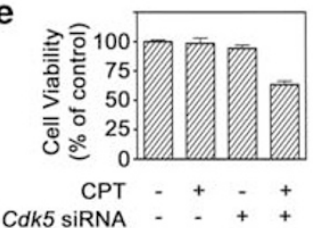

Cdk5 SIRNA - ++

Figure 9 Cdk5 siRNA inhibits EKR1/2 phosphorylation and Bcl-2 expression and enhances camptothecin-induced apoptosis in human neurons. (a) Primary cultures of human neurons. The human neurons were cultured in the medium (medium) and treated with camptothecin (CPT) after transfected with nonspecific siRNA or Cdk5 siRNA. (b) Camptothecin dose response curve. Human neurons, either nontransfected or transfected with Cdk5 siRNA, were treated with various doses of camptothecin for $24 \mathrm{~h}$ and subjected to cell viability analysis. (c) Cdk5 siRNA transfection. Human neurons were transfected with Cdk5 siRNA for $24 \mathrm{~h}$ and then treated with $300 \mathrm{ng} / \mathrm{ml}$ BDNF for $6 \mathrm{~h}$ before subjected to Western blot analysis of ERK1/2 phosphorylation and Bcl-2 expression. Actin was used as protein loading control. (d) Caspase-3 cleavage. The Cdk5 siRNA-transfected human neurons as described above (c) were treated with $100 \mathrm{ng} / \mathrm{ml}$ camptothecin for $10 \mathrm{~h}$ and then subjected to Western blot analysis for expression of $\mathrm{Cdk5}, \mathrm{Bcl}-2$, enolase and neurofilament (NF) proteins and cleavage of capase-3. (e) Cell death. The Cdk5 siRNA-transfected human neurons were further treated with $100 \mathrm{ng} / \mathrm{ml}$ camptothecin for $16 \mathrm{~h}$ and examined by cell viability analysis (mean \pm S.E.M.; $n=4$ ) 
indeed detected a significant decrease of the expression of Cdk5 and Bcl-2 and phosphorylated ERK1/2 (Figure 9c and d). Transfection of Cdk5 siRNA did not affect expression of neuronal proteins such as enolase and neurofilament (NF) (Figure 9d). The Cdk5 siRNA-transfected human neurons were then treated with various doses of camptothecin to determine if the inhibition of $\mathrm{Cdk} 5$ renders the human neurons vulnerable to camptothecin. Phase contrast microscopy showed cellular apoptosis (Figure 9a), Western blots detected cleavage of caspase-3 (Figure $9 d$ ) and cell viability assay revealed enhanced cell death (Figure $9 \mathrm{~b}$ and e) in camptothecin-treated human neurons-transfected with Cdk5 siRNA. The results validate the finding observed in the study of SH-SY5Y cells that Cdk5-mediated ERK1/2 and Bcl-2 pathway contributes to BDNF neuroprotection of human neurons against DNA damage-induced apoptosis.

\section{Discussion}

Transgenic mice provided the first evidence that p35/Cdk5 kinase activity is required for neuronal survival during the development of the nervous system. ${ }^{9}$ Studies of rat neurons in culture have further demonstrated that NGF and BDNF induce p35/Cdk5 kinase activity for neuronal survival. ${ }^{13}$ Through a systematic analysis of the interaction between BDNF-induced p35/Cdk5-mediated pathway and camptothecin-induced apoptotic pathway during SH-SY5Y neuronal differentiation, we report here that BDNF-induced p35/Cdk5 activity upregulates $\mathrm{Bcl}-2$ through $\mathrm{ERK} 1 / 2$ pathway during neuronal differentiation and the ERK1/2-mediated Bcl-2 expression contributes to Ckd5-mediated neuronal survival (Figure 10).

NGF and BDNF induce p35/Cdk5 kinase activity during neuronal differentiation in culture. ${ }^{13,20}$ We have further shown that BDNF treatment upregulates p35 and activates Cdk5 kinase, thus protecting the differentiated neuron-like cells from DNA damage-induced apoptosis. Inhibition of Cdk5

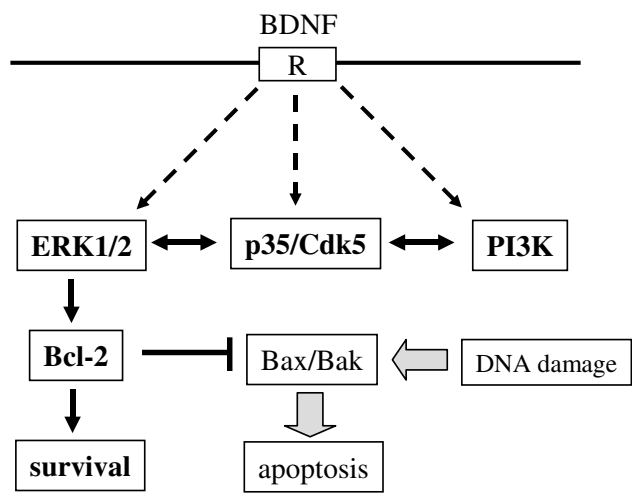

Figure 10 Schematic diagram of ERK1/2-mediated Bcl-2 expression for BDNF-induced Cdk5-mediated neuroprotection. The BDNF treatment induces p35 expression and thus Cdk5 kinase activation. BDNF activates ERK1/2 and PI3K pathway through Ras and Raf pathway for neuronal survival. ${ }^{19}$ Inhibition of p35/Cdk5 prevents ERK1/2 and PI3K activation; the results suggest that Cdk5 is required for ERK1/2 and PI3K activation during the BDNF-induced neuronal differentiation. Inhibition of ERK1/2, but not PI3K, downregulates Bcl-2, suggesting that ERK1/2 pathway mediates Bcl-2 expression. Bcl-2 inhibits Bax and Bak apoptotic functions and thus protects neurons from DNA damageinduced activation of mitochondrial pathway kinase activity with either its pharmacological inhibitor or synthetic siRNA resulted in vulnerability of the differentiated cells to DNA damage agents such as camptothecin, providing clear evidence that Cdk5 activity is required for neuronal survival during neuronal differentiation. Mature murine cortical neurons ${ }^{18}$ and human fetal neurons, as demonstrated in this study, undergo apoptosis after exposure to high toxic doses of camptothecin; however, inhibition of Cdk5 renders the human neurons more vulnerable to camptothecin-induced apoptosis. Clearly, the results presented here demonstrate that Cdk5mediated signal events play an important role in protection of primary human neurons from DNA damage insults.

NGF activates the PI3K/Akt pathway during PC12 cell differentiation ${ }^{35}$ perhaps through Ras and Raf pathway. ${ }^{19}$ Cdk5 knockout mice show inhibition of the PI3K/Akt pathway in neurons. ${ }^{12}$ Cdk5 phosphorylates the neuregulin receptor ErbB2/3 and thus is involved in neuregulin-induced Akt activity and neuregulin-mediated neuronal survival. ${ }^{12}$ An earlier study indicated that Akt phosphorylates Bad, a Bcl-2 family member, for cell survival. ${ }^{36}$ In this study, we have shown that BDNF-induced Cdk5 kinase activity upregulated Bcl-2 during the neuronal differentiation. Inhibition of PI3K in the differentiated cells, however, neither prevented Cdk5-mediated $\mathrm{Bcl}-2$ upregulation nor sensitized the cells to the DNA damage-induced apoptosis. Therefore, the BDNF-induced Cdk5-mediated Bcl-2 pathway for neuronal survival occurs through a PI3K/Akt-independent pathway.

Studies of PC12 cells have shown that MAPK/ERK $1 / 2$ mediates NGF-induced Cdk5 kinase activity. ${ }^{13}$ The finding in this study that inhibition of Cdk5 activity inhibits ERK1/2 phosphorylation further supports the notion that the ERK1/2 pathway involves in the Cdk5-mediated cell signal events. NGF has been reported to activate the Bcl-2 promoter through MEK/MAPK in PC12 cells, ${ }^{37}$ while NGF induces $\mathrm{Bcl}-2$ expression in sympathetic neurons through cyclic adenosine monophosphate (CAMP) response element binding protein (CREB)-dependent transcriptional mechanisms. ${ }^{38}$ Here, we demonstrate that $\mathrm{Cdk5}$-mediated $\mathrm{Bcl}-2$ upregulation occurs through the ERK1/2 pathway during neuronal differentiation and ERK1/2-mediated Bcl-2 expression contributes to Cdk5mediated neuronal survival. Clearly, further investigation of the interactions between Cdk5-mediated signaling pathways and apoptotic pathways will shed more light on the molecular mechanisms that control neuronal death and survival during neuronal differentiation and disease.

\section{Materials and Methods}

\section{SH-SY5Y cell culture and differentiation}

Human SH-SY5Y neuroblastoma cell line (kindly provided by Dr JX Comella, Lleida, Spain) was grown in Dulbecco's modified Eagle's medium (DMEM) supplemented with $2 \mathrm{mM}$ L-glutamine, penicillin (20 units $/ \mathrm{ml})$, streptomycin $(20 \mu \mathrm{g} / \mathrm{ml})$, and 10\% (vol/vol) heat-inactivated fetal calf serum (GIBCO) at $37^{\circ} \mathrm{C}$ in a saturated humidity atmosphere containing $95 \%$ air and $5 \% \mathrm{CO}_{2}$. Cells were differentiated into neuronal phenotype as described previously. ${ }^{21}$ Briefly, cells were seeded at an initial density of $10^{4}$ cells $/ \mathrm{cm}^{2}$ in culture dishes and incubated for five days in the medium with $10 \mu \mathrm{M}$ 13-cis-retinoic acid (RA, Sigma). The cells were then incubated in serum-free DMEM with $100 \mathrm{ng} / \mathrm{ml}$ BDNF (Alomone 
Labs, Har Botzvim Hi-Tech Park, Jerusalem, Israel) for an additional 5 days to generate the differentiated SH-SY5Y-N cells. The differentiated and undifferentiated cells were treated with camptothecin, cisplatin and etoposide (Sigma) in the presence or absence of the caspase- 9 inhibitor zLEHD-fmk (R\&D) or the pan-caspase inhibitor z-VAD-fmk (R\&D). Cell viability was determined using the trypan blue exclusion assay. The cells were also treated with the Cdk5 inhibitor roscovitine (Sigma), the PI3K inhibitor LY294002 and the MEK1 inhibitor PD98059 (Cell Signaling).

\section{Human neuron culture}

Human neuron cultures were prepared from brains of human embryos of 10-18 weeks gestation that were obtained at therapeutic abortions as approved by local institutional ethics committees. ${ }^{33}$ In brief, $5-15 \mathrm{~g}$ of brain were diced into fragments of $1 \mathrm{~mm}$ and incubated for $15 \mathrm{~min}$ at $37^{\circ} \mathrm{C}$ in $40 \mathrm{ml}$ PBS containing $0.25 \%$ trypsin and $200 \mu \mathrm{g} / \mathrm{ml}$ DNAse I. The suspension was washed through a filter of $130 \mu \mathrm{M}$ pore size and the filtrate was centrifuged at $1200 \mathrm{rpm}$ for $10 \mathrm{~min}$. The cell pellet was resuspended in PBS and centrifuged again. The cell pellet was suspended and cultured in DMEM supplemented with 10\% heat-inactivated fetal calf serum (GIBCO), $0.1 \%$ dextrose and antibiotics, and cells were plated directly either into 96 well plates or culture flasks coated with $10 \mu \mathrm{g} / \mathrm{ml}$ polylysine. The cells were cultured for 2 days in cytosine arabinosidecontaining medium and an additional 3 days in the medium free of cystosine arabinoside at $37^{\circ} \mathrm{C}$ in a saturated humidity atmosphere containing $95 \%$ air and $5 \% \mathrm{CO}_{2}$.

\section{Transfection of cDNA constructions and siRNA duplexes}

SH-SY5Y cells grown to $50 \%$ confluency were transfected with $\mathrm{Bcl}-2$ expressing pUSEamp plasmid (Bcl-2/pUSEamp, Upstate, Lake Placia, NY) using LipofectAMINE ${ }^{\mathrm{TM}}$ Plus (Invitrogen). Two Bcl-2 siRNA duplexes (Bcl-2-siRNA1: 5'-GACUCUGCUCAGUUUGGCC-3', 3'-GGCCAAACU GAGCAGAGUC-5'; Bcl-2-siRNA2: 5'-CAUCGCCCUGUGGAUGACU-3', 3'-AGUCAUCCACAGGGCGAUG-5') were synthesized, purified and annealed by Qiagen-Xeragon (Germantown, USA). The siRNA duplex targeting Cdk5 (Smartpool ${ }^{\mathrm{TM}}$ ) and nonspecific control of siRNA were purchased from Upstate Biotechnology (Dharmacon). SH-SY5Y-N cells and human fetal neurons were transfected for $24 \mathrm{~h}$ with $2 \mu \mathrm{g}$ of each siRNA using the TransMessenger transfection reagent following the manufacturer's protocol (Qiagen). The cultures were then treated with chemotherapy agents and subjected to Western blot and cell death analyses.

\section{Cdk5 kinase assay}

Cdk5 proteins were immunoprecipitated from cells using polyclonal rabbit anti-Cdk5 antibody (c-8; Santa Cruz Biotechnology, Santa Cruz, USA). Briefly, a total volume of $50 \mu \mathrm{l}$ of kinase assay mixture containing $10 \mu \mathrm{l}$ washed Cdk5 protein beads (Protein G-Sepharose; Amersham Biotech) in $20 \mathrm{mM}$ MOPS (pH 7.4) with $1 \mathrm{mM}$ EGTA, $1 \mathrm{mM}$ dithiothreitol, $20 \mathrm{mM}$ $\mathrm{MgCl}_{2}$ and $100 \mu \mathrm{M}$ ATP plus $10 \mu \mathrm{g}$ of histon- $\mathrm{H} 1$ and $5 \mu \mathrm{Ci}\left[\gamma^{32} \mathrm{P}\right] \mathrm{ATP}$ was assembled. After incubation for $30 \mathrm{~min}$ at $30{ }^{\circ} \mathrm{C}$, the reaction was terminated by spotting $30 \mu \mathrm{l}$ of the reaction mixture on P81 phosphocellulose pads (Upstate) that were washed five times with $0.75 \%$ phosphoric acid followed by rinsing with acetone. Radioactivity was measured with a liquid scintillation counter.

\section{Flow cytometry}

Cells $\left(10^{6}\right)$ treated with camptothecin were harvested, washed and incubated for $40 \mathrm{~min}$ at $4^{\circ} \mathrm{C}$ with either mouse IgG1 antibody as a negative control or a mouse monoclonal antibody against Bak $N$ terminus (AB-1, Oncogene; diluted 1:50 in $100 \mu \mathrm{g} / \mathrm{ml}$ digitonin in PBS). After being washed with PBS, the binding of antibody was visualized with FITC-conjugated antimouse-lgG (1:200) (Sigma), and 10000 cells were analyzed. The data were processed using Cell Quest ${ }^{\mathrm{TM}}$ software (Becton and Dickinson).

\section{Subcellular fractionation}

Subcellular fractionation was performed based on our protocol. ${ }^{39}$ Subconfluent cells treated as indicated in the RESULTS were harvested, and the cell pellet was suspended in 5 volumes of isotonic buffer $(10 \mathrm{mM}$ HEPES-KOH (pH 7.5), $210 \mathrm{mM}$ mannitol, $70 \mathrm{mM}$ sucrose, $1 \mathrm{mM} \mathrm{Na-}$ EDTA, and $1 \mathrm{mM} \mathrm{Na-EGTA)} \mathrm{supplemented} \mathrm{with} 1 \mathrm{mM}$ phenylmethylsulfonyl fluoride and protease inhibitor mixture. The cells were incubated on ice for $15 \mathrm{~min}$ and passed through a 22-gauge needle 15 times. After centrifugation twice at $700 \times g$ for $10 \mathrm{~min}$ at $4^{\circ} \mathrm{C}$, the supernatant was collected and centrifuged at $13000 \times g$ for $10 \mathrm{~min}$ at $4^{\circ} \mathrm{C}$. The resulting mitochondrial pellets were suspended in lysis buffer $(50 \mathrm{mM}$ Tris- $\mathrm{HCl}(\mathrm{pH}$ 7.4), $150 \mathrm{mM} \mathrm{NaCl}, 2 \mathrm{mM}$ EDTA, $10 \%$ glycerol, $1 \%$ Triton-X 100, $1 \mathrm{mM}$ PMSF, and $0.2 \%$ protease inhibitor cocktail). The supernatants of the $13000 \times g$ spin were further centrifuged at $100000 \times g$ for $1 \mathrm{~h}$ at $4^{\circ} \mathrm{C}$, and the resulting supernatants were designated as the S-100 cytosolic fractions. The protein concentrations in the cytosolic and mitochondrial fractions were determined by the Bradford assay (Bio-Rad), and equal amounts of mitochondrial and cytosolic proteins were subjected to Western blot analysis.

\section{Western blots}

For Western blot analysis, ${ }^{39}$ cells were harvested and lysed in a cold lysis buffer (50 mM Tris (pH 7.4), $150 \mathrm{mM} \mathrm{NaCl}, 2$ mM EDTA, 10\% glycerol, 1\% Triton X-100, $1 \mathrm{~mm}$ PMSF and $1 \%$ protease inhibitor mixture). The cell lysates were centrifuged for $15 \mathrm{~min}$ at $18000 \times g$ at $4^{\circ} \mathrm{C}$, supernatants were collected and protein concentrations in the supernatant were determined by the Bio-Rad protein assay (Bio-Rad Laboratories). The cell lysates $(50 \mu \mathrm{g})$, as well as the cytosolic or mitochondrial fractions $(10 \mu \mathrm{g})$ from the subcellular fractionation were subjected to SDS-polyacrylamide electrophoresis and transferred to nitrocellulose membranes. The membranes were blocked in TBS-T (Tris-buffered saline with $0.05 \%$ Tween-20) containing 5\% milk and blotted overnight with various primary antibodies. The membranes were washed and incubated for $1 \mathrm{~h}$ with either horseradish peroxidase (HRP)-conjugated goat anti-mouse or goat antirabbit antibodies (Southern Biotech, Birmingham). The membranes were washed and developed by chemiluminescence. Mouse monoclonal antibodies used in this study included anti-human caspase-8 (Medical \& Biological Laboratories, Nagoya, Japan), and cytochrome $c$ oxidase IV (Molecular Probes, Eugene, USA). Rabbit polyclonal antibodies included anti-human caspase-3, DFF45, ERK1/2 (StressGen, Victoria), Bid (Biosource International Inc., Camarillo), Bak, cytochrome c (Upstate Biotechnology, Lake Placid), Bcl-2, Bax, Cdk5, p35, $\beta$-actin (Santa Cruz Biotechnology, Santa Cruz), p53, p-ERK1/2, p-Akt, Akt (Cell Signaling), Bcl- $X_{L}$ and PARP-1 (Biomol, Plymouth Meeting). Densitometric analysis of protein expression levels was performed with UVP Bioimaging Systems (UVP Inc., Upland, CA). 


\section{Acknowledgements}

We thank Dr. Eric Sandberg for critically reading this manuscript. This work was supported in part by funds from the Department of Pathology and Laboratory Medicine at Emory University $(\mathrm{CH})$ and the Canadian Institute of Health Research Grants (CW, AS and VWY). C Hao is the Georgia Cancer Coalition Distinguished Scholar.

\section{References}

1. Lew J, Beaudette K, Litwin CM and Wang JH (1992) Purification and characterization of a novel proline-directed protein kinase from bovine brain. J. Biol. Chem. 267: 13383-13390

2. Tsai LH, Delalle I, Caviness Jr VS, Chae T and Harlow E (1994) p35 is a neuralspecific regulatory subunit of cyclin-dependent kinase 5 . Nature 371: 419-423

3. Tang D, Yeung J, Lee KY, Matsushita M, Matsui H, Tomizawa K, Hatase $\mathrm{O}$ and Wang JH (1995) An isoform of the neuronal cyclin-dependent kinase 5 (Cdk5) activator. J. Biol. Chem. 270: 26897-26903

4. Hellmich MR, Pant HC, Wada E and Battey JF (1992) Neuronal cdc2-like kinase: a cdc2-related protein kinase with predominantly neuronal expression. Proc. Natl. Acad. Sci. USA 89: 10867-10871

5. Zheng M, Leung CL and Liem RK (1998) Region-specific expression of cyclin-dependent kinase 5 (cdk5) and its activators, p35 and p39, in the developing and adult rat central nervous system. J. Neurobiol. 35: 141-159

6. Patrick GN, Zukerberg L, Nikolic M, de la Monte S, Dikkes P and Tsai LH (1999) Conversion of p35 to p25 deregulates Cdk5 activity and promotes neurodegeneration. Nature 402: 615-622

7. Wang J, Liu S, Fu Y, Wang JH and Lu Y (2003) Cdk5 activation induces hippocampal CA1 cell death by directly phosphorylating NMDA receptors. Nat. Neurosci. 6: 1039-1047

8. Song JH, Wang CX, Song DK, Wang P, Shuaib A and Hao C (2005) Interferon gamma induces neurite outgrowth by up-regulation of p35 neuron-specific cyclin-dependent kinase 5 activator via activation of ERK $1 / 2$ pathway. J. Biol. Chem. 280: 12896-12901

9. Chae T, Kwon YT, Bronson R, Dikkes P, Li E and Tsai LH (1997) Mice lacking p35, a neuronal specific activator of Cdk5, display cortical lamination defects, seizures, and adult lethality. Neuron 18: 29-42

10. Gupta A, Sanada K, Miyamoto DT, Rovelstad S, Nadarajah B, Pearlman AL, Brunstrom J and Tsai LH (2003) Layering defect in p35 deficiency is linked to improper neuronal-glial interaction in radial migration. Nat. Neurosci. 6 : 1284-1291

11. Nikolic M, Chou MM, Lu W, Mayer BJ and Tsai LH (1998) The p35/Cdk5 kinase is a neuron-specific Rac effector that inhibits Pak1 activity. Nature 395: 194-198

12. Li BS, Ma W, Jaffe H, Zheng Y, Takahashi S, Zhang L, Kulkarni AB and Pant HC (2003) Cyclin-dependent kinase-5 is involved in neuregulin-dependent activation of phosphatidylinositol 3-kinase and Akt activity mediating neuronal survival. J. Biol. Chem. 278: 35702-35709

13. Harada T, Morooka T, Ogawa S and Nishida E (2001) ERK induces p35, a neuron-specific activator of Cdk5, through induction of Egr1. Nat. Cell Biol. 3: 453-459

14. Ashkenazi A and Dixit VM (1998) Death receptors: signaling and modulation. Science 281: 1305-1308

15. Newmeyer DD and Ferguson-Miller S (2003) Mitochondria: releasing power for life and unleashing the machineries of death. Cell 112: 481-490

16. Luo X, Budihardjo I, Zou H, Slaughter C and Wang X (1998) Bid, a Bcl2 interacting protein, mediates cytochrome $\mathrm{C}$ release from mitochondria in response to activation of cell surface death receptors. Cell 94: 481-490

17. Li P, Nijhawan D, Budihardjo I, Srinivasula SM, Ahmad M, Alnemri ES and Wang X (1997) Cytochrome $C$ and dATP-dependent formation of Apaf-1/ caspase-9 complex initiates an apoptotic protease cascade. Cell 91: 479-489

18. Stefanis L, Park DS, Friedman WJ and Greene LA (1999) Caspase-dependent and -independent death of camptothecin-treated embryonic cortical neurons. J. Neurosci. 19: 6235-6247
19. Huang EJ and Reichardt LF (2001) Neurotrophins: roles in neuronal development and function. Annu. Rev. Neurosci. 24: 677-736

20. Troy CM, Rabacchi SA, Hohl JB, Angelastro JM, Greene LA and Shelanski ML (2001) Death in the balance: alternative participation of the caspase-2 and -9 pathways in neuronal death induced by nerve growth factor deprivation. J. Neurosci. 21: 5007-5016

21. Encinas M, Iglesias M, Liu Y, Wang H, Muhaisen A, Cena V, Gallego $C$ and Comella JX (2000) Sequential treatment of SH-SY5Y cells with retinoic acid and brain-derived neurotrophic factor gives rise to fully differentiated, neurotrophic factor-dependent, human neuron-like cells. J. Neurochem. 75: 991-1003

22. Chipuk JE, Kuwana T, Bouchier-Hayes L, Droin NM, Newmeyer DD, Schuler M and Green DR (2004) Direct activation of Bax by p53 mediates mitochondrial membrane permeabilization and apoptosis. Science 303: 1010-1014

23. Li H, Zhu H, Xu CJ and Yuan J (1998) Cleavage of BID by caspase 8 mediates the mitochondrial damage in the Fas pathway of apoptosis. Cell 94: 491-501

24. Hopkins-Donaldson S, Bodmer JL, Bourloud KB, Brognara CB, Tschopp J and Gross N (2000) Loss of caspase-8 expression in highly malignant human neuroblastoma cells correlates with resistance to tumor necrosis factor-related apoptosis-inducing ligand-induced apoptosis. Cancer Res. 60: 4315-4319

25. Liu X, Zou H, Slaughter C and Wang X (1997) DFF, a heterodimeric protein that functions downstream of caspase-3 to trigger DNA fragmentation during apoptosis. Cell 89: 175-184

26. Gross A, Jockel J, Wei MC and Korsmeyer SJ (1998) Enforced dimerization of $B A X$ results in its translocation, mitochondrial dysfunction and apoptosis. EMBO J. 17: 3878-3885

27. Griffiths GJ, Dubrez L, Morgan CP, Jones NA, Whitehouse J, Corfe BM, Dive C and Hickman JA (1999) Cell damage-induced conformational changes of the pro-apoptotic protein Bak in vivo precede the onset of apoptosis. J. Cell Biol. 144: $903-914$

28. Oltvai ZN, Milliman CL and Korsmeyer SJ (1993) Bcl-2 heterodimerizes in vivo with a conserved homolog, Bax, that accelerates programmed cell death. Cell 74: 609-619

29. Yi X, Yin XM and Dong Z (2003) Inhibition of Bid-induced apoptosis by Bcl-2. tBid insertion, Bax translocation, and Bax/Bak oligomerization suppressed. J. Biol. Chem. 278: 16992-16999

30. Crews CM, Alessandrini A and Erikson RL (1992) The primary structure of MEK, a protein kinase that phosphorylates the ERK gene product. Science 258: $478-480$

31. Franke TF, Yang SI, Chan TO, Datta K, Kazlauskas A, Morrison DK, Kaplan DR and Tsichlis PN (1995) The protein kinase encoded by the Akt proto-oncogene is a target of the PDGF-activated phosphatidylinositol 3-kinase. Cell 81: 727-736

32. Alessi DR, Cuenda A, Cohen P, Dudley DT and Saltiel AR (1995) PD 098059 is a specific inhibitor of the activation of mitogen-activated protein kinase kinase in vitro and in vivo. J. Biol. Chem. 270: 27489-27494

33. Vecil GG, Larsen PH, Corley SM, Herx LM, Besson A, Goodyer CG and Yong VW (2000) Interleukin-1 is a key regulator of matrix metalloproteinase-9 expression in human neurons in culture and following mouse brain trauma in vivo. J. Neurosci. Res. 61: 212-224

34. Hetman M, Kanning K, Cavanaugh JE and Xia Z (1999) Neuroprotection by brain-derived neurotrophic factor is mediated by extracellular signal-regulated kinase and phosphatidylinositol 3-kinase. J. Biol. Chem. 274: 22569-22580

35. Yao R and Cooper GM (1995) Requirement for phosphatidylinositol-3 kinase in the prevention of apoptosis by nerve growth factor. Science 267: 2003-2006

36. Datta SR, Dudek H, Tao X, Masters S, Fu H, Gotoh Y and Greenberg ME (1997) Akt phosphorylation of BAD couples survival signals to the cell-intrinsic death machinery. Cell 91: 231-241

37. Liu YZ, Boxer LM and Latchman DS (1999) Activation of the Bcl-2 promoter by nerve growth factor is mediated by the p42/p44 MAPK cascade. Nucleic Acids Res. 27: 2086-2090

38. Riccio A, Ahn S, Davenport CM, Blendy JA and Ginty DD (1999) Mediation by a CREB family transcription factor of NGF-dependent survival of sympathetic neurons. Science 286: 2358-2361

39. Song JH, Song DK, Pyrzynska B, Petruk KC, Van Meir EG and Hao C (2003) TRAIL triggers apoptosis in human malignant glioma cells through extrinsic and intrinsic pathways. Brain Pathol. 13: 539-553 